\title{
Synthesis and pharmacological evaluation of N-[4-(t-amino)-2- butynyloxy] phthalimides
}

\author{
Zuhair Muhi-eldeen ${ }^{1}$, Elham Al-kaissi ${ }^{2}$, Riad Awad1, Najah Al-Muhtaseb1, Kassim Al- \\ shamma ${ }^{3}$ \\ 1Department of Medicinal chemistry and Pharmacognosy, Faculty of Pharmacy, Petra University, Amman, Jordan, \\ 2Department of Pharmaceutics and biotechnology, Faculty of Pharmacy, Petra University, Amman, Jordan. \\ 3Dept. of Pharmacology and Toxicology, College of Pharmacy, Baghdad University, Baghdad, Iraq, cc.
}

\section{Graphical abstract}

Anew series of N-[4-(t-amino)-2-butynyloxy] phthalimides were synthesized and investigated for their pharmacological activity in comparism with harmaline<smiles>[R]C1CCCC([R])N1CC#CC#CCON1C(=O)c2ccccc2C1=O</smiles>

Where $\mathrm{R}=\mathrm{CH} 3, \mathrm{R}^{`}=\mathrm{H}$

$\mathrm{R}=\mathrm{R}^{`}=\mathrm{CH} 3$

$\mathrm{n}=0,1$

\begin{abstract}
A series of aminoacetylenicoxyphthalimide namely $\mathrm{N}$-[4-(t-amino)-2-butynyloxy] phthalimides were synthesized from the reaction of $\mathrm{N}$-hydroxyphthalimide with propargyl bromide in sodium ethoxide to generate $\mathrm{N}$-(2-butynyloxy)phthalimide. The desired compounds were prepared through Mannich reaction of $\mathrm{N}$-(2-butynyloxy)phthalimide with formaldehyde, appropriate amine in peroxide-free dioxin and cuprous chloride as catalyst. The $\mathrm{N}$-[4-(t-amino)-2-butynyloxy] phthalimides were investigated for their rectal temperature, motor activity and palpebral pitosis effects in comparison with harmaline, all compounds showed similar activity to harmaline, however compound 4 was more potent than harmaline.
\end{abstract}

Keywords: Aminoacetylenicoxyphthalimide, aminoacetylenic moiety, locomotors activity, MAO inhibitors, oxyphthalimide derivatives, palpebral pitosis

\section{Introduction}

Acetylenic compounds and in particular aminoacetylenic compounds are of importance in many types of pharmacological activity. These activities may be shown in 0xotremorine antagonists [1,2,3], their effects on behavioral functional changes and central motor effects [4, 5]. Aminoacetylenic compound showed Monoaminooxidase inhibitory activity type B as seen with Rasagiline (Azilect ${ }^{\circledR}$ )in treatment of Parkinson's disease [6,7], Clorgyline a drug used in depression treatment through monoaminooxidase A inhibition [8, 9, 10]. Furthermore, acetylenic compounds block $\mathrm{H} 3$ receptor and play important role in treatment of Alzheimer and other neurodegenerative disorders as seen with Perceptin [11]. In looking at the structural features of the above mentioned drugs and going through most recent publications $[12,13]$ and to be away from their classical approaches we felt it will be of great interest to synthesize a novel series of N-[4-(t-amino)-2-butynyloxy] phthalimides (Table 1) and investigate their pharmacological activity. These aminoacetylenic compounds showed similar activity to harmaline in regard rectal hypothermic effects, spontaneous motor activity after reserpine treatment and inhibition of palpebral pitosis induce by reserpine. N-[4-(2,6-dimethylpiperidino)-2-butynyloxy] phthalimides 4 was equal or more than harmaline in potency. 
Drugs with aminoacetylenic moiety

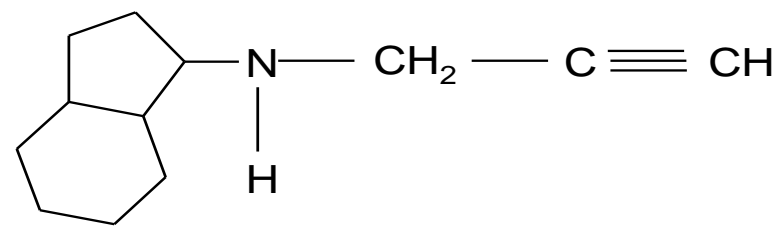

Azilect<smiles>C#CCN(C)CCOc1cc(Cl)cc(Cl)c1</smiles>

Clorgyline

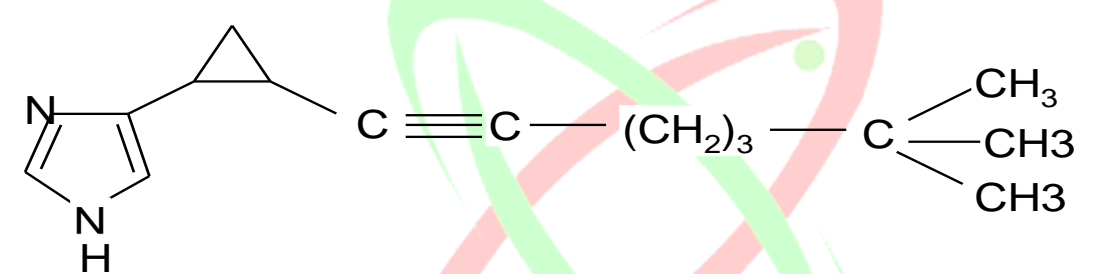

Perceptin<smiles>[R]C(C#Cc1ccccc1)N1C(=O)CCC1=O</smiles>

Oxotremorine antagonist 


\section{Materials and Methods}

2. 1. Compounds synthesized<smiles>O=C1c2ccccc2C(=O)N1OCC#CCN1CCCC1</smiles><smiles>O=C1c2ccccc2C(=O)N1OCC#CCN1CCCCC1</smiles>

2<smiles>CC1CCCCN1CC#CCON1C(=O)c2ccccc2C1=O</smiles><smiles>CC1CCCC(C)N1CC#CCON1C(=O)c2ccccc2C1=O</smiles>

4

\subsection{Chemistry:}

Melting points were determined by using a calibrated Thomas- Hoover melting apparatus. IR spectra were recorded using a Perkin-Elmer 257 spectrophotometer, 1H and 13CNMR were acquired with the aid of Bruker - DpX300 MHZ spectrometer with DMSO-d6 as solvent and TMS as internal standard.

Microanalysis were performed in the laboratories of Dr.BernHardt, Mulheim, West Germany. The analyses were indicated only by symbols of the elements analyzed; the results obtained had a maximum deviation of $\pm 0.4 \%$ from the theoretical value. 
2. 2.1. N-(2-butynyloxy) phthalimide

A solution of sodium $n$-hydroxyphthalimide $(0.01$, mole) in $30 \mathrm{ml}$ benzene was refluxed to $40 \mathrm{oC}$. propargyl bromide $(0.015$ mole) was added drop wise to the solution during 30 minutes. The mixture was stirred for 2 hours and then filtered. The solvent was removed under reduced pressure to afford the desired compound $(1.2 \mathrm{~g} \%)$ as a white crystalline powder. $\mathrm{mp}$, (145-146 oC). IR ( $\mathrm{KBr}, \mathrm{Cm}-1)$ : 3264 ( $\mathrm{C} \equiv \mathrm{CH}$, stretch), 3050 ( ArH, stretch), 2245 (C $\equiv \mathrm{CH}$, stretch), 1720 (C=O, stretch) 1612, 1553, 1396 ( $\mathrm{Ar}, \mathrm{C}=\mathrm{C}$, stretch), 1000-900 (C=C, bending), 800, 695, 635 (ArH, bending). 1HNMR (DMSO-d6): $\delta$, 3.52, (t, $1 \mathrm{H}, \mathrm{J}=2.02 \mathrm{~Hz}, \mathrm{C} \equiv \mathrm{CH}), 4.53(\mathrm{~d}, 2 \mathrm{H}, \mathrm{J}=2.02 \mathrm{~Hz}, \mathrm{~N}-\mathrm{CH} 2-\mathrm{C} \equiv)$, 7.78-7.9 (m ,4H, ArH). 13CNMR (DMSO-d6): 52 (C, O-CH2), $75(\mathrm{C}, \equiv * \mathrm{CH}), 79(\mathrm{C} \equiv * \mathrm{CH}), 123,131,135(\mathrm{Ar}), 176\left({ }^{*} \mathrm{C}=\mathrm{O}\right.$, imide). Anal.Calcd, (C11H7N1O3): C, 65,67; H, 3.50; N, 6.99. Found. C, 65.70; H, 3.54; N, 7.04.

2. 2. 2. N-(4-t-amino-2-butynyloxy)phthalimides. 1-4.

A mixture of $\mathrm{n}$-(proargyloxy) phthalimide ( 0.04 mole), paraformaldehyde $(0.042 \mathrm{~mole})$ and cuprous chloride (catalytic amount) in peroxide- free dioxane ( $20 \mathrm{ml}$ ) was heated at $50 \mathrm{oC}$ for 2-3 hours. After cooling, water (100ml) was added and the crude product was recrystallized from ethanol-water.

The physical properties of the prepared oxyphthalimides are listed in table1. The IR spectra showed the following characteristic absorption bands (CHCL3, cm-1), $3040(\mathrm{CH}, \mathrm{ArH}$ stretch), 2150 (very weak, $\mathrm{C} \equiv \mathrm{C}$, stretch)1780. $1720(\mathrm{C}=\mathrm{O}$, imide, stretch).

The 1HNMR and 13CNMR are shown separately for each compound.

2. 2. 3. N-[4-(1-pyrrplidino)-2-butynyloxy] phthalimide. 1

The titled compound was prepared following the general procedure for synthesis of $\mathrm{N}$-[4-(t-amino)-2-butynyloxy] phthalimides. The mp, yield \% and Ir were shown in (Table1) and synthetic procedure. 1HNMR (DMSO-d6): $\delta, 1.9,(\mathrm{~m}, 4 \mathrm{H}$, $\left.10 \mathrm{CH} 2-10{ }^{\circ} \mathrm{CH} 2\right) 1.6\left(\mathrm{~m}, 4 \mathrm{H}, 9 \mathrm{CH} 2-9{ }^{\circ} \mathrm{CH} 2\right), 3.05(\mathrm{t}, 2 \mathrm{H}, \mathrm{J}=2.4 \mathrm{~Hz}, \equiv \mathrm{C}-8 \mathrm{CH} 2-\mathrm{N}), 3.75(\mathrm{t}, 2 \mathrm{H}, \mathrm{J}=2.4 \mathrm{~Hz}, 5 \mathrm{CH} 5), 7.6$ (d,1H, $\mathrm{J}=4.2 \mathrm{H} 4, \mathrm{Ar} 2 \mathrm{H}), 7.8(\mathrm{~d}, 1 \mathrm{H}, \mathrm{J}=4.2 \mathrm{HZ}, \mathrm{Ar} 1 \mathrm{H}), 13 \mathrm{CNMR}$ (DMSO-d6): $\delta, 24\left(10,10^{`} \mathrm{C}\right), 27.4\left(9,9^{\circ} \mathrm{C}\right), 52.9(8 \mathrm{C}), 58.5(5 \mathrm{C})$, 78.2 (2,2`C), 79.5 (1,1`C), 135.2 (3,3`C), 177.1 (4,4C). Anal. Calcd. ( C16H16N2O3).

C, $67.60 ; \mathrm{H}, 5.64$; N, 9.86. Found C, 67.58 ; H, $5.60 ; \mathrm{N}, 9.82$.

2. 2. 4. N-[4-(1-pyrrplidino)-2-butynyloxy] phthalimide. 2

Description of synthesis, mp.\% yield and IR are shown in (Table 1) and preparation of N-[4-(t-amino)-2-butynyloxy] phthalimides. . 1HNMR (DMSO-d6): $\delta, 1.53,(\mathrm{~m}, 2 \mathrm{H}, 11 \mathrm{CH} 2) 1.59$ (m, 4H,10CH2-10`CH2), 1.64 (m, 4H, 9CH2-9'CH2`), $3.4(\mathrm{t}, 2 \mathrm{H}, \mathrm{J}=2.4 \mathrm{~Hz}, 8 \mathrm{CH} 2-\mathrm{N}), 3.75(\mathrm{t}, 2 \mathrm{H}, \mathrm{J}=4.4 \mathrm{~Hz}, \mathrm{O}-5 \mathrm{C}-\equiv \mathrm{C}), 7.6\left(\mathrm{~d}, 1 \mathrm{H}, \mathrm{J}=4.2 \mathrm{~Hz}, \mathrm{Ar} 2,2^{\prime} \mathrm{H}\right), 7.8(\mathrm{~d}, 1 \mathrm{H}, \mathrm{J}=4.2 \mathrm{HZ}$, Ar,1`1H), 13CNMR (DMSO-d6): $\delta, 24.03(11 \mathrm{C}), 25.8\left(10,10^{\circ} \mathrm{C}\right), 27.4$ (9,9 $\left.9^{`} \mathrm{C}\right), 52.9(8 \mathrm{C}), 58.5(5 \mathrm{C}), 78.2$ (2,2`C), 79.5

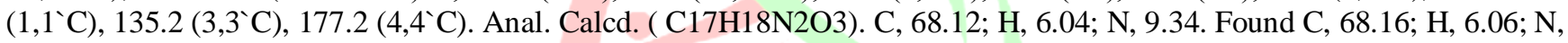
9.79 .

2. 2. 5. N-[4-(2-methypiperidino)-2-butynyloxy] phthalimide. 3

The title compound was prepared following the same procedure described for compounds 1-4 . 1HNMR (DMSO-d6): $\delta$, 1.12 , (d, $\left.3 \mathrm{H}, \mathrm{J}=4.2 \mathrm{~Hz}, 13 \mathrm{CH} 3) 1.5\left(\mathrm{~m}, 6 \mathrm{H}, 10 \mathrm{CH} 2-10^{\circ} \mathrm{CH} 2-11 \mathrm{CH} 2\right), 1.5(\mathrm{~m}, 2 \mathrm{H}, 9 \mathrm{CH} 2), 1.64(\mathrm{~m}),, 1 \mathrm{H}, 9^{\circ} \mathrm{CH} 2\right), 3.4(\mathrm{t}, 2 \mathrm{H}$, $\mathrm{J}=2.4 \mathrm{~Hz}, 8 \mathrm{CH} 2-\mathrm{N}), 3.75(\mathrm{t}, 2 \mathrm{H}, \mathrm{J}=2.4 \mathrm{~Hz}, \mathrm{O}-5 \mathrm{CH} 2-\mathrm{C} \equiv), 7.6\left(\mathrm{~d}, 1 \mathrm{H}, \mathrm{J}=4.2 \mathrm{~Hz}, \mathrm{Ar} 2,2^{`} \mathrm{H}\right), 7.8\left(\mathrm{~d}, 1 \mathrm{H}, \mathrm{J}=4.2 \mathrm{HZ}, \mathrm{Ar}, 1^{`} 1 \mathrm{H}\right)$, 13CNMR (DMSO-d6): $\delta, 20.0$ (12C), 24.9 (11C), $26.2\left(10^{\circ} \mathrm{C}\right), 27.4(10 \mathrm{C}), 32.8$ ( $\left.9^{\circ} \mathrm{C}\right), 52.9$ (8C-C $\left.\equiv\right), 58.5$ ( O-5C-C $\left.\equiv\right)$, 78.2 (2,2 C), 79.5 (1,1 $\left.{ }^{`} \mathrm{C}\right), 135.2$ (3,3 C), 177.2 (4,4 C). Anal. Calcd. ( C17H18N2O3): C, 69.22; H, 6.4; N, 9.29. Found: C, $69.45 ; \mathrm{H}, 6.45 ; \mathrm{N}, 9.31$.

2. 2. 6. N-[4-(2,6-dimethypiperidino)-2-butynyloxy] phthalimide. 4

The title compound was prepared following the same procedure described for compounds 1-4 . 1HNMR (DMSO-d6): $\delta$, 1.14, (d, 3H, J=4.2Hz, ( 12,12` CH3) 1.5 (m, 6H,10CH2-10`CH2-11CH2), $1.80\left(\mathrm{~m}, 2 \mathrm{H}, 9,9^{`} \mathrm{CH} 2\right.$ ), $3.5(\mathrm{t}, 2 \mathrm{H}, \mathrm{J}=2.4 \mathrm{~Hz}$, $8 \mathrm{CH} 2-\mathrm{N}), 3.75(\mathrm{t}, 2 \mathrm{H}, \mathrm{J}=2.4 \mathrm{~Hz}, \mathrm{O}-5 \mathrm{CH} 2-\mathrm{C} \equiv), 7.6\left(\mathrm{~d}, 1 \mathrm{H}, \mathrm{J}=4.2 \mathrm{~Hz}, \mathrm{Ar} 2,2^{\prime} \mathrm{H}\right), 7.8\left(\mathrm{~d}, 1 \mathrm{H}, \mathrm{J}=4.2 \mathrm{HZ}, \mathrm{Ar},{ }^{\prime} 1 \mathrm{H}\right), 13 \mathrm{CNMR}$ (DMSO-d6): $\delta, 22.01\left(12,12^{\circ} \mathrm{C}\right), 24.03(11 \mathrm{C}), 25.8\left(10,10^{\circ} \mathrm{C}\right), 27.1$ (9, $\left.9^{\circ} \mathrm{C}\right), 52.9$ (8C-C $\left.\equiv\right), 58.5(\mathrm{O}-5 \mathrm{C}-\mathrm{C} \equiv), 78.2\left(2,2^{\circ} \mathrm{C}\right)$, 79.3 (1,1 $\left.{ }^{`} \mathrm{C}\right), 135.1$ (3,3`C), 177.3 (4,4`C). Anal. Calcd. ( C17H18N2O3): C, 69.91; H, 6.44; N, 8.58. Found: C, 69.94; H, $6.47 ; \mathrm{N}, 8.60$. 
Table 1: N-[4-(t-amino)-2-butynyloxy] phthalimides

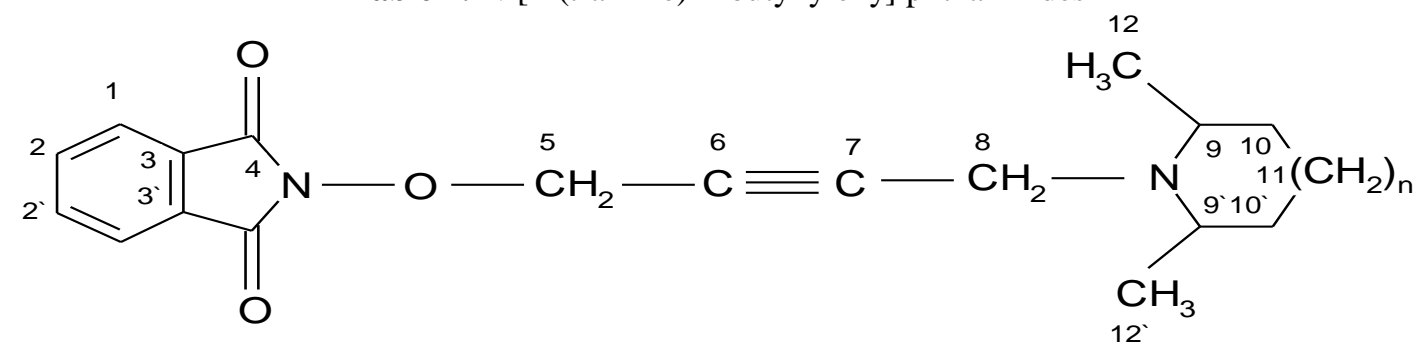

\begin{tabular}{|l|l|l|l|l|l|l|}
\hline $\begin{array}{l}\text { Compound } \\
\text { No. }\end{array}$ & R1 & R2 & n & yield & Formula & m.p. \\
oC *
\end{tabular}

*All derivatives were crystallized from ethanol -water , all were analyzed

for $\mathrm{C}, \mathrm{H}$ and $\mathrm{N}$.

**the 2,6-dimethyl in 4 are cis (diequatorial).

\section{3. Pharmcology:}

\section{3. 1. Animals}

Albino Wistar rats of either sex, weighing 200-350 g were used throughout the study. They were maintained on a $12 \mathrm{hrs}$ light-dark cycle and fed a commercial chow, water was given ad libitum. Rectal temperature was measured with thermistor probe and recorded on temperature recorder type Z94-B (ellab*). The resting temperature was first recorded, and then the test compound dissolved in sterile saline was injected intravenously. Rectal temperature was recorded again 2.5 hours after injection of compounds $1-4(2 \mathrm{mg} / \mathrm{kg})$ and 15 minutes after injection of harmaline $(0.1 \mathrm{mg} / \mathrm{kg})$.the same scheme was used for reserpinized rats. Reserpine (Ciba. $2 \mathrm{mg} / \mathrm{kg}$ )was injected intravenously 2 hours after the compounds $1-4$ and 15 minutes after harmaline. Another record of the temperature was taken 30 minutes after reserpine injection. Palpebral pitosis was recorded on rats before and 30 minutes after reserpine injection. Other records were taken after administration of harmaline, compounds 1-4 plus reserpine. Scoring was based on a scale from 0 to 4 , were 0 corresponds to totally open eye and 4 to totally closed eye. Albino mice were used for measurement of motor activity. Spontaneous motor activity was measured by using open field test [14]. The number of squares traversed by each mouse during 5 minutes was recorded before and after reserpine injection. Other records were taken after administration of harmaline, compounds 1-4 plus reserpine. For palpebral pitosis and motor activity, reserpine was injected intravenously 2 hours after the injection of compounds 1-4 and 15 minutes after the harmaline injection. Records were then taken 30 minutes after reserpine. In reserpinized animals, the dose of harmaline used was $2 \mathrm{mg} / \mathrm{kg}$.

\section{Pharmacological results}

The hypothermic effects for harmaline and compounds 1-4 on the body temperature of rats were shown in (Table 2). The mean change in body temperature for compounds $1-4$ were $-0.5 \mathrm{oC},-0.7 \mathrm{oC},-0.75 \mathrm{oC},-0.84 \mathrm{oC}$ respectively; and $-0.82 \mathrm{oC}$ for harmaline. The hypothermic effect of harmaline was significantly higher than compounds 1-3 and less than that of compound 4. The results of prevention of hyperthermia induced by reserpine administration were shown in (Table 3). The initial response in rats to reserpine injection is hyperthermia $+1.08 \pm 0.02$. Harmaline modify this response and induce hypothermia in rats previously treated with reserpine. Compounds 1-3 induce a similar effect to harmaline but at a lower rate, on the other hand compound 4 induce significantly similar hypothermic effect to harmaline. The mean change in body temperature was $-0.26 \mathrm{oC},-0.3 \mathrm{oC},-0.35 \mathrm{oC}$ and $-0.42 \mathrm{oC}$ for compounds $1-4$ respectively, while harmaline induced a mean change of -0.41 oC. Reserpine depressed significantly the motor activity of mice. The mean number of squares traversed by the mice in 5 minutes was changed from 110 to 22 by reserpine administration. Harmaline and compound 4 antagonize almost completely this depression. Compound 1-3 were less active (Table 4).

The prevention of palpebral 
pitosis induced by reserpine administration in rats is illustrated in (Table 5). Reserpine induced a complete pitosis. Harmaline and compound 4 completely antagonized this pitosis, while compounds 1-3 partially antagonize the pitosis.

Table 2:

Hypothermic effect of the synthesized compounds compared with Harmaline

\begin{tabular}{|l|l|}
\hline Treatment & Mean change in rectal temperature oC \\
\hline Saline & $+0.05 \pm 0.02$ \\
\hline Compound 1 & $-0.5 \pm 0.06^{*}$ \\
\hline Compound 2 & $-0.7 \pm 0.2^{*}$ \\
\hline Compound 3 & $-0.75 \pm 0.2^{*}$ \\
\hline Compound 4 & $-0.84 \pm 0.2^{*}$ \\
\hline Harmaline ( reference compound) & $-0.82 \pm 0.1$ \\
\hline
\end{tabular}

$* \mathrm{P}>0.05$ when compared with saline treated animals

Hypothermic effects of the MAO inhibitor (Harmaline dose $0.1 \mathrm{mg} / \mathrm{kg}$ ) and compounds $1-4$ (dose $2 \mathrm{mg} / \mathrm{kg}$ ) in rats. Values represent the mean difference of 6 rats \pm S.E.M. between the rectal temperature before and 2.5 hours after the intravenous injections of compounds 1-4 and 15 minutes after Harmaline injection. Rectal temperature was $37.1 \pm 0.2$ before treatment.

Table 3 :

Rectal temperature changes after pretreatment with Reserpine

\begin{tabular}{|l|l|}
\hline Treatment & Mean change in rectal temperature oC \\
\hline Reserpine & $+1.08 \pm 0.02$ \\
\hline Compound 1 & $-0.26 \pm 0.01^{*}$ \\
\hline Compound 2 & $-0.3 \pm 0.03^{*}$ \\
\hline Compound 3 & $-0.35 \pm 0.03^{*}$ \\
\hline Compound 4 & $-0.42 \pm 0.03^{*}$ \\
\hline Harmaline & $-0.41 \pm 0.05$ \\
\hline
\end{tabular}

$* \mathrm{P}>0.05$ when compared with Reserpine treated animals

Rectal temperature was measured after reserpine alone, and after harmaline, compounds 1-4 plus Reserpine. Data are reported as the difference between the initial rectal temperature and the temperature of 45 minutes after harmaline administration and 2.5 hours after compounds 1-4 administration. Reserpine was injected 30 minutes before the second temperature reading. Data are presented as the mean \pm S.E.M. for six rats. Doses of reserpine, compounds 1-4 and harmaline were $2 \mathrm{mg} / \mathrm{kg}$ given intravenously. 
Table 4:

Spontaneous motor activity after reserpine treatment, followed by harmaline and compounds 1-4.

\begin{tabular}{|l|l|}
\hline Treatment & $\begin{array}{l}\text { Mean number of square traversed by the mice } \\
\text { during 5 minutes. }\end{array}$ \\
\hline Saline & $110 \pm 17$ \\
\hline Reserpine & $22^{*} \pm 7$ \\
\hline Compound 1 & $97^{*} \pm 5$ \\
\hline Compound 2 & $99^{*} \pm 12$ \\
\hline Compound 3 & $100^{*} \pm 9$ \\
\hline Compound 4 & $110^{*} \pm 11$ \\
\hline Harmaline & $110 \pm 11$ \\
\hline
\end{tabular}

$* \mathrm{P}>0.05$ when compared with saline treated animals

Spontaneous motor activity after reserpine alone or after harmaline, compounds 1-4 plus reserpine. Each value represents a mean value \pm S.E.M. for 10 mice. Doses of reserpine, compounds $1-4$ and harmaline were $2 \mathrm{mg} / \mathrm{kg}$ given intravenously.

\section{Table 5:}

Inhibition of palpebral pitosis induce by reserpine

\begin{tabular}{|l|l|}
\hline Tretment & Pitosis rating \\
\hline Saline & 0 \\
\hline Reserpine & $4 \pm 0$ \\
\hline Compound 1 & $0.5 \pm$ \\
\hline Compound 2 & $0.3 \pm 0.2$ \\
\hline Compound 3 & $1.0 \pm 0.2$ \\
\hline Compound 4 & 0.0 \\
\hline Harmaline & 0 \\
\hline
\end{tabular}

Palpebral pitosis induced by reserpine and blocked by harmaline and compounds 1-4 administration in rats. Each value represents a mean for 6 rats \pm S.E.M..

\section{Discussion}

The induction of hypothermia in rats may suggest that compounds 1-4 are MAO inhibitors. It is well known that MAO inhibitors such as clorgyline, harmaline, (-) deprenyl and pargyline can induce similar effects in rats in doses range from 0.1$1 \mathrm{mg} / \mathrm{kg}$ [15]. The hypothermic activity of MAO inhibitors is probably due to their ability in preventing the metabolism of amines such as dopamine, tyramine or tryptamine [15]. Dopamine produces hypothermia when injected into rat brain ([16]. However, the above test is not sufficient to indicate that these compounds are MAO inhibitors. CNS depressant in general produces hypothermia [17]. The experiments with reserpinized animals give more clear evidence on the MAO inhibitory activity of these four compounds. In rats, the initial response to reserpine injection is hyperthermia followed within hours by hypothermia. Pretreating rats with MAO inhibitors (Clorgyline and harmaline in dose of $2 \mathrm{mg} / \mathrm{kg}$ ) modify the response to reserpine and the hypothermia is the initial response [15]. Harmaline and compounds 1-4 were significantly block the hyperthermia induced by reserpine is probably due to the presence of 2-phenylethylamine chromophor within $\beta$ - carboline [15]. Since reserpine releases endogenous amines from their storage sites $[18,19]$. 
Reserpine depresses the motor activity of animals. However, while MAO inhibitors (harmaline) and compounds 1-4 significantly antagonize this depression. The prevention of depression in motor activity is probably due to the released amines such as noradrenaline and 5HT $[15,20]$. The results of palpebral pitosis is in agreement with the suggestion that compounds 1-4 have MAO inhibitor activity. Palpebral pitosis after reserpine is probably due to the depletion of noradrenaline from sympathetic neurons [21]. Sympathetic neurons contain primarily MAO - A enzymes and noradrenaline is a substrate for MAO - A enzymes [15]. All the data from reserpinized rats and mice clearly support the suggestion that compound 1-4 have MAO inhibition activity. However, compounds 1-3 are weaker than harmaline as MAO inhibitor, while compound 4 is equally active or more potent than harmaline in the entire previous tests that is related to MAO inhibitory activity. Harmaline which is used in this work as standard MAO - A inhibitors might be more useful as antidepressents than the non specific inhibitor drugs [15]. Prior treatment of rats with MAO - A inhibitor prevents the depression of motor activity, palpebral pitosis and initial hyperthermia induced by treatment with reserpine. MAO - B inhibitors were ineffective in these tests, this suggested that dopamine and the other common substrates as well as the specific substrate for MAO - B are not responsible for much of the pharmacology of reserpine [15]. So the results of this work showed clear blockage to the depression of motor activity, palpebral pitosis and initial hyperthermia induced by reserpine. This indicated that compounds 1-4 are probably inhibit MAO - A enzymes. The order of activity for compounds 1-4 indicate that increase in the hydrocarbon that lead to higher lipophilicity afforded greater activity as seen with compound 4. Work in progress to verify the selectivity of compounds 1-4 toward MAO - A inhibitory activity.

\section{Conclusion}

The synthesis of aminoacetylenicoxyphthalimide and their pharmacological data provide a new series of compounds with specific MAO - A inhibitory activity. Further investigation is undergoing to confirm their selectivity towards MAO - A enzyme.

\section{References}

[1] B. Ringdahl, Z. Muhi-Eldeen, C. Ljunggren, B. Karlen, B. Resul, R. Dahlbom, and D. J. Jenden, Acetylene compounds of potential pharmacological value, XXVIII. Oxotremorine analogues substituted with a methyl group in the lactam ring, Acta pharmac. Suec., 16, 1979, 89-94.

[2] Z. Eldeen, A. Shbber, N. Musa, A. Muhammed, A. Khayat, and H. Ghantous, Synthesis and biological evaluation of N-(4-t-amino-2-butynyloxy) and N-(4-t-amino-2-butynyl)phthalimides, Eur. J. Med. Chem., 15, 1980, 85-88.

[3] R. Dahlbom, D. J. Jenden, B. Resul, and B. Ringdahl, Sterochemical requirements for central and peripheral muscarinic and antimuscarinic activity of some acetylenic compounds related to oxotremorine, Br. J. Pharmac., 76, 1982, 299-304,

[4] M. Ukai, N. Shinkai, and T. Kameyama, Cholinergic receptor agonists inhibit pirenzepine-induced dysfunction of spontaneous alternation performance in the mouse, General pharmacology: the vascular system, 26 (7), 1995, 15291532.

[5] I. Jurna, W. Grossmann, and T. Well, depression by amantadine of tremor induced by reserpine and oxotremorine in the rat, Archives of Pharmacology, 280 (2), 1973, 141-152.

[6] S. S. Roa, L. A. Hofmann, and A. Shkil, Parkinson's disease: diagnosis and treatment, Am. Fam. Physician., 74 (12), 2006, 2046-2060.

[7] J. G. Nut, and G. F. Wooten, Clinical practice: Diagnosis and initial management of Parkinson's disease, N. Eng. 1. J. Med., 353, 2005, 1021-1027.

[8] C. B. Seymour, C. Mothersill, R. Mooney, M. Moriarty, and K. F. Tipton, Monoamine oxidase inhibitors L-deprenyl 
and clorgyline protect nonmalignant human cells from ionizing radiation and chemotherapy toxicity, B. J. C., 89, 2003, 1969-1986.

[9] J. S. Fowler, J. Logan, Y. S. Ding, D. Franceschi, G. J. Wang, N. D. Volkow, N. Pappas, D. Schlyer, S. J. Gatley, D. Alexoff, C. Felder, A. Biegon, and W. Zhu, Non-MAO a binding of clorgyline in white matter in human brain, J. Neurochem.,79 (5), 2001, 1039-1046.

[10] B. Gao, W. C. Duncan, JR., and T. A. Wehr, Clorgyl-induced reduction in body temperature and its relationship to vigilance states in Syrian hamsters, Neuropsychopharmacology, 4 (3), 1991, 187-197.

[11] G. Jackson, and C. Owsley, Visual dysfunction, neurodegenerative diseases, and aging, Neurologic Clinics, 12(3), 2003, 709-728.

[12] M. R. Suryawanshi, V. M. Kulkarni, K. R. Mahadik, and S. H. Bhosale, Synthesis, Pharmacological evaluation and QSAR Study of 2-aryl-1H-[1, 3,4]oxadiazino[5, 6- b]quinoxalines as Antidepressants, Arch. Appl. Sci. Res., 3 (1), $2011,380-391$.

[13] C. Lamanna, M. S. Sinicropi, P. Pietrangeli, F. Corbo, C. Franchini, B. Mondovi, M. G. Perrone, and A. Scilimati, Synthesis and biological evaluation of 3-alkyloxazolidine-2-ones as reversible MAO inhibitors, ARKIVOC, (V), 2004, 118-130.

[14] R. Brimblecombe, and A. Green, Effects of MAO inhibitors on the behavior of rats in Hall's open field, Nature, 194, 1962, 983.

[15] N. Neff, and J. Fuentes, The use of selective monoamine oxidase inhibitor drugs for evaluating pharmacological and physiological mechanism, In Ciba foundation Symposium 39, 1976, Elsevier-Excepta MadiaNorth Holland, 163-72.

[16] Z. L. Kruk, The effect of drugs acting on dopamine receptors on the body temperature of the rat. Life Sci., 11, $1972,845-850$.

[17] J. W. Bastian, Classification of CNS drugs by a mouse screening. Arch Int Pharmacodyn Ther. Oct 1; 133, 1961, 347-364.

[18] B. B. Brodie, J. S.Olin, R. Kuntzman, and P. A. Shore, Possible interrelationship between release of brain norepinephrine and serotonin by reserpine. Science, 125, 1957, 1293-1294.

[19] M. Holzbauer, \& M. Vogt, Depression by reserpine of the noradrenaline concentration in the hypothalamus of the cat. J. Neurochem. 1, 1956, 8-11.

[20] A. Christmas, C. Coulson, D. Maxwell, and D. Riddel, A comparison of the pharmacological and biochemical properties of substrate-selective monoamine oxidase inhibition, Br. J. pharmacol., 45, 1972, 490-503.

[21] D. Tedeschi, P. Fowler, and R. Miller, Mechanisms underlying reserpine-induced pitosis and blepharospasm: Evidence that reserpine decreases central sympathetic out-flow in rats, Life sci., 6, 1967, 515-523. 